\title{
A comparison of phytotoxic potential among the crude extracts from Parthenium hysterophorus $L$. extracted with solvents of increasing polarity
}

\author{
Ujjal Kumar Pati ${ }^{*}$, Ashim Chowdhury \\ Department of Agricultural Chemistry \& Soil Science, IAS, University of Calcutta, 35-B.C. Road, \\ Kolkata - 700019, India \\ *E-mail address: ujjalkrpati@gmail.com
}

\begin{abstract}
There is a worldwide search for the safe, effective and eco-friendly compounds of plant origin to combat the weed species and other pests which are responsible for the great impact on the growth and productivity of agricultural crops. In this present study, a comparison was made to evaluate the phytotoxicity potential of sequentially extracted solvent (hexane, ethyl-acetate, methanol) extracts of Parthenium hysterophorus L. (aerial parts) in vitro through bench-top seed germination assay (Vigna radiata L.). One-way analysis of variance (ANOVA) followed by Duncan's multiple range test (DMRT) were done for statistical analysis of the data. The study reveals that germination, growth and vigour was significantly $(\mathrm{P}<0.05)$ reduced by ethyl-acetate and methanol extracts. The present study concluded that phytotoxicity of ethylacetate and methanolic crude extracts of Parthenium hysterophorus could be exploited as potential bioherbicide for future weed management programme and the development of bioherbicide for commercial use.
\end{abstract}

Keywords: Parthenium hysterophorus; phytotoxicity; Vigna radiate; bioassay; hexane; ethylacetate and methanol

\section{INTRODUCTION}

Synthetic chemicals improved crop yields quantitatively and qualitatively but has created undesirable impacts on health, environmental quality and development of resistance and cross resistance. Due to these problems, there is a serious efforts to find alternatives to these chemicals. Among those alternatives, phytochemicals shows a potential approach for the management of noxious and other pests in a proper manner. Besides pest management they are environment friendly, because they are biodegradable, rarely contain halogenated atoms, and possess novel target sites that are different from synthetic chemicals. They also exhibit a large degree of novelty and structural diversity and are highly sought after for the discovery of new agrochemicals. The discovery of novel modes of action would lead to the development of new weed management tools.

There are many weed species that are phytotoxic in nature. Among the weeds Parthenium hysterophorus L., is an aggressive weed native to Southern North America, Central America, the West Indies and Central South America[1], having allelopathic effect and drastically retards the growth of many species[2]. Parthenium is an invasive exotic weed 
commonly known as Bitter weed, False ragweed, Fever few, Ragweed, Carrot weed, White top, Chatak chandani, Congress grass \& Star weed. Its botanical name is Parthenium hysterophorous L. and belongs to the Class: Magnoliopsida, Family: Asteraceae (Compositae). It is a herbaceous plant, and a native of Tropical America. It is an annual herb and has a deep taproot and erect stem, which becomes woody with age. Height varies of Parthenium weed between 50-150 cm, leaves are deeply lobed. It is pale green in colour and has soft hair. Parthenium weed flower is creamy white in color. The weed has a large number of highly branched stems. It has small (1-2mm long) black seeds with white scales. They are not visible to the naked eye. The countries where it has been reported with the presence of this weed are South Africa, Mozambique, Madagascar in Africa, China, India, Vietnam, Nepal in Asia, Guatemala, Honduras, Belie etc. in Central America, Mexico, in South America and in United States [3].

The successful spread of Parthenium in so many parts of the world including India has mainly been attributed to its allelopathic properties, which enables it to compete effectively with crops and pasture species[4]. It can play an important roles in the determination of plant diversity[5], dominance, succession, and climax of natural vegetation and in the plant productivity of agro ecosystems. Apart from its competitive ability, the invasiveness of the noxious weed $P$. hysterophorus L., is thought to be due to an ability to displace other species by means of allelopathy. The allelochemicals released from Parthenium affecting many plant species are sesquiterpene lactones and phenolics[6]. Parthenin is the major sesquiterpene lactone whereas caffeic, vanillic, ferulic, chlorogenic and anisic acids are the major phenolics[7,8]. These two synergistically acting groups of allelochemicals signifi-cantly decrease the seed germination and subsequent growth in many crops [8].

\section{MATERIAL AND METHODS}

\subsection{Plant material for extraction}

The plant sample (Parthenium hysterophorous L) was collected from local vegetation of Baruipur, 24-Paraganas (south) $\left[22^{0} 21\right.$ '29"N Latitude and $88^{0} 2637^{\prime \prime} \mathrm{E}$ Longitude and altitude of 42 feet] , West Bengal, India. The samples were cut into small pieces, air dried at room temperature $\left(25 \pm 3^{\circ} \mathrm{C}\right)$, then oven dried for 2 days at $40^{\circ} \mathrm{C}$ and powdered by mechanical grinder to store in air tight packets which are now ready for experiment.

\subsection{Seed material for bioassay}

Vigna radiata $\mathrm{L}$. Seeds were used in this experiment as target organism for bioassay. The seed materials were procured from the Department of Agronomy, BCKV, Mohanpur, Kalyani, Nadia (W.B.).

\subsection{Extraction}

The crude extracts were prepared by macerating $250 \mathrm{gm}$. of powdered Parthenium with 1 L. solvents of choice with increasing polarity (hexane, ethyl-acetate and methanol) following exhaustive sequential extraction. Extraction was done in multiple set and pooled together. The crude extracts were filtered through Whatman No.1 filter paper and were evaporated to a gummy mass, which were then diluted with minimum solvents \& remaining 
with distilled water to get $10 \%, 25 \%, 50 \%, 75 \%$ and $100 \%(\mathrm{v} / \mathrm{v})$ test extracts for further testing.

\subsection{Bioassay}

$10 \%, 25 \%, 50 \%, 75 \%, 100 \%(\mathrm{v} / \mathrm{v})$ test extracts thus obtained from hexane, ethyl acetate and methanol crude extracts were used for bioassay along with a treatment as control with distilled water. A commercial herbicide Pendiguard (pendimethylene 50\%EC) at FR dose was used as standard check control. Physiological Experiments of the investigation were carried out with viable surface sterilized seeds of Vigna radiata, pretreated with the test extracts of different concentrations for $2 \mathrm{hrs}$, and placed in Petri dishes containing moistened filter paper.

Germination data were recorded every $12 \mathrm{hr}$. intervals up to $120 \mathrm{hr}$ of seed soaking following the International Rules for Testing[9]. Seven germination indices, germination percentage (GP), germination index (GI), germination energy (GE), speed of emergence (SE), mean germination time (MGT), seedling vigour index (SVI), and coefficient of the rate/velocity of germination (CRG) were obtained \& then calculated from the same data by using the equations[10] described below (Table-1). Morphological parameters like root length, shoot length and seedling height were measured in fresh samples after $120 \mathrm{hrs}$. Phytoxicity, inhibition and relative root elongation were calculated following the equations[11] described. One-way analysis of variance (ANOVA) followed by Duncan's multiple range test (DMRT) were done for statistical analysis of the data.

Table 1. Equations used to calculate Germination indices and other physiological parameters.

\begin{tabular}{|c|c|}
\hline Germination parameters & $\begin{array}{l}\text { Equation } \\
\end{array}$ \\
\hline Germination percent (GP) & $\begin{array}{c}\mathrm{GP}=[\text { (number of germinated seeds at final count)/total number of } \\
\text { seeds sets for bioassay }] \times 100\end{array}$ \\
\hline Germination index (GI) & $\mathrm{GI}=\sum \mathrm{G}_{\mathrm{T}} / \mathrm{T}_{\mathrm{t}} \mathrm{G}_{\mathrm{T}}=$ number of germinated seeds, $\mathrm{T}_{\mathrm{t}}=$ time in days \\
\hline $\begin{array}{l}\text { Mean germination time } \\
\text { (MGT) }\end{array}$ & $\begin{array}{c}\text { MGT }=\left[\sum\left(\mathrm{T}_{\mathrm{i}} \times \mathrm{N}_{\mathrm{i}}\right) / \sum \mathrm{N}_{\mathrm{i}}\right] \\
\mathrm{N}_{\mathrm{i}}=\text { number of newly germinated seeds at time } \mathrm{T}_{1} \text {. }\end{array}$ \\
\hline Seedling vigour index (SVI) & $\mathrm{SVI}=($ seedling length $\times$ germination percent $) / 100$ \\
\hline Speed of emergence (SE) & $\begin{array}{c}\mathrm{SE}=(\text { number of germinated seeds at the starting day of } \\
\text { germination/number of germinated seeds at the final day of } \\
\text { measurements }) \times 100\end{array}$ \\
\hline Germination energy (GE) & $\begin{array}{c}\mathrm{GE}=(\text { percent of germinated seeds at the day of germination/total } \\
\text { number of seeds set for bioassay) } \times 100\end{array}$ \\
\hline $\begin{array}{l}\text { Coefficient of the rate of } \\
\text { germination }(\mathrm{CRG})\end{array}$ & $\begin{array}{c}\mathrm{CRG}=\left[\left(\mathrm{N}_{1}+\mathrm{N}_{2}+\ldots \ldots \mathrm{N}_{\mathrm{n}}\right) /\left(\mathrm{N}_{1} * \mathrm{~T}_{1}\right)+\left(\mathrm{N}_{2} * \mathrm{~T}_{2}\right)+\ldots . .\left(\mathrm{N}_{\mathrm{n}} * \mathrm{~T}_{\mathrm{n}}\right)\right]^{*} 100 \\
\text { where } \mathrm{N}_{1}=\text { number of germinated seeds at time } \mathrm{T}_{1}, \mathrm{~N}_{2}=\text { number of } \\
\text { germinated seeds at time } \mathrm{T}_{2}, \mathrm{~N}_{\mathrm{n}}=\text { number of germinated seeds at } \\
\text { time } \mathrm{T}_{\mathrm{n}}\end{array}$ \\
\hline Phytotoxicity & $\begin{array}{l}\text { (Root length in control - Root length in treatment)/Root length } \\
\text { in control }\end{array}$ \\
\hline Inhibition & $\begin{array}{c}100-\left(\mathrm{E}_{2} \times 100 / \mathrm{E}_{1}\right), \text { Where } \mathrm{I}=\% \text { Inhibition, } \mathrm{E}_{1}=\text { Response in } \\
\text { control, } \mathrm{E}_{2}=\text { Response in treatment plant. }\end{array}$ \\
\hline Relative root Elongation & $\begin{array}{c}\mathrm{R}=(\mathrm{L} / \mathrm{Lr}) \times 100 \text {, where } \mathrm{R} \text { is the relative root elongation, } \mathrm{L} \text { is the } \\
\text { mean root length in treatments, } \mathrm{Lr} \text { is mean root length the of } \\
\text { control. }\end{array}$ \\
\hline
\end{tabular}




\section{RESULTS}

The hexane, ethyl acetate and methanol crude extracts of Parthenium were used to study the germination process of $V$. radiata seeds upto $120 \mathrm{hrs}$. The Germination Kinetics was studied for the three crude extracts (Figure-1). It has been revealed that there are nonsignificant changes in germination kinetics (Figure-1A) in hexane crude dilutions where as there is a significant changes in germination kinetics among the treatments of ethyl-acetate (Figure-1B) and methanol (Figure-1C) crudes. The ethyl-acetate treatments show a 50\% reduction of germination in comparison to control (100\% germination). Table-2-4 shows the effect of crude extract dilutions on germination indices.
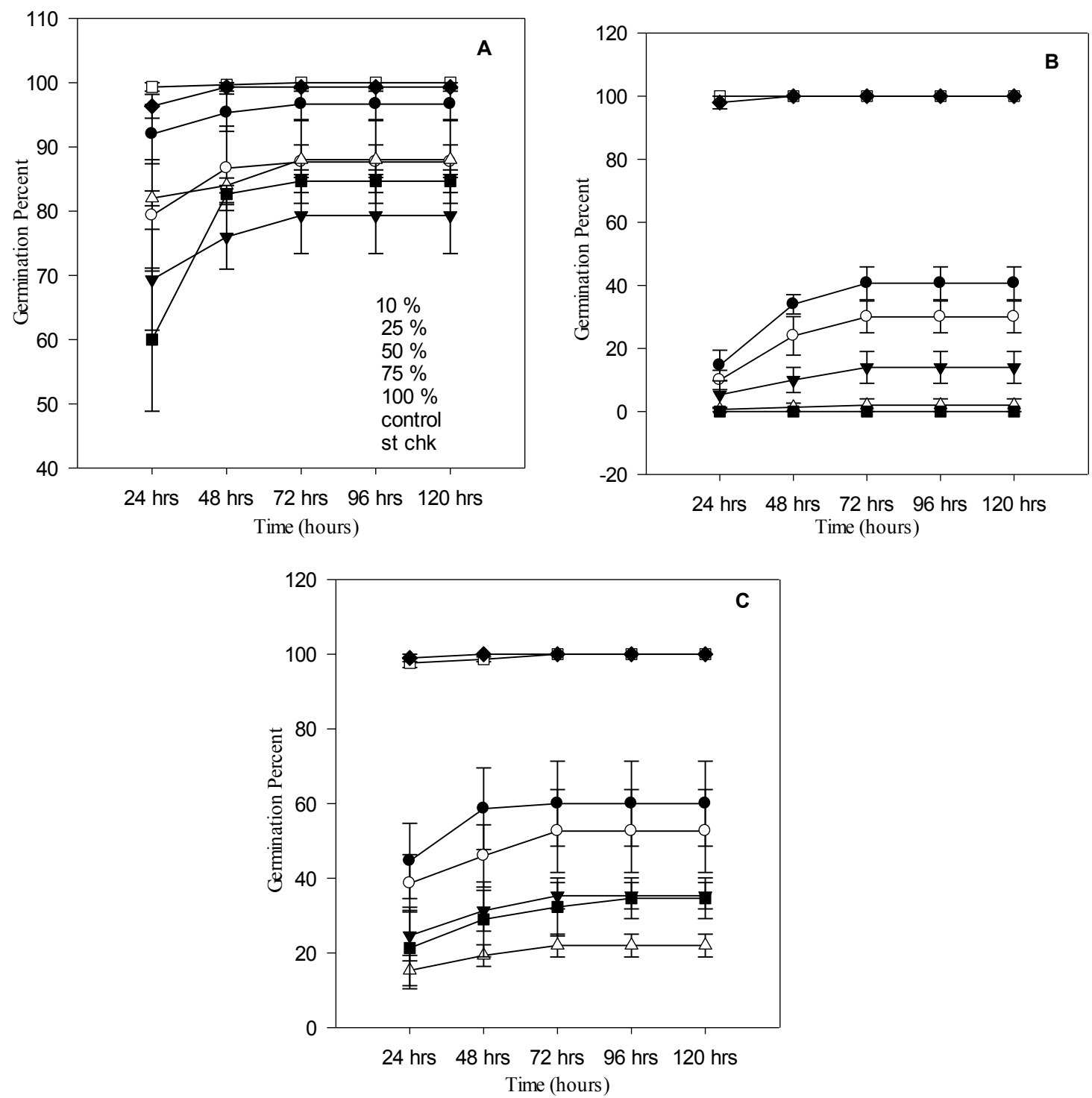

Figure 1. Germination kinetics of germinating $V$. radiata seeds treated with different concentrations of crude extracts of Parthenium (A- hexane; B- ethylacetate; C- methanol crudes). 
Table 2. Effect of hexane crude extract dilutions of Parthenium on germination.

\begin{tabular}{cccccccc}
\hline TREATMENTS & GP & GI & MGT & CRG & SE & GE & SVI \\
\hline $\mathbf{1 0}$ & $96.67^{\mathrm{ab}}$ & $94.11^{\mathrm{abc}}$ & $1.06^{\mathrm{d}}$ & $94.22^{\mathrm{ab}}$ & $95.06^{\mathrm{a}}$ & $96.67^{\mathrm{ab}}$ & $18.49^{\mathrm{cd}}$ \\
$\mathbf{2 5}$ & $87.67^{\mathrm{bc}}$ & $83.33^{\mathrm{cd}}$ & $1.11^{\mathrm{d}}$ & $90.32^{\mathrm{ab}}$ & $90.07^{\mathrm{a}}$ & $87.67^{\mathrm{bc}}$ & $22.45^{\mathrm{bcd}}$ \\
$\mathbf{5 0}$ & $79.33^{\mathrm{c}}$ & $73.78^{\mathrm{d}}$ & $1.17^{\mathrm{cd}}$ & $85.45^{\mathrm{bc}}$ & $86.85^{\mathrm{a}}$ & $79.33^{\mathrm{c}}$ & $18.62^{\mathrm{cd}}$ \\
$\mathbf{7 5}$ & $88.00^{\mathrm{bc}}$ & $84.34^{\mathrm{cd}}$ & $1.11^{\mathrm{d}}$ & $90.20^{\mathrm{ab}}$ & $93.27^{\mathrm{a}}$ & $88.00^{\mathrm{bc}}$ & $18.81^{\mathrm{cd}}$ \\
$\mathbf{1 0 0}$ & $84.67^{\mathrm{c}}$ & $72.00^{\mathrm{bcd}}$ & $1.32^{\mathrm{bc}}$ & $77.10^{\mathrm{cd}}$ & $70.75^{\mathrm{b}}$ & $84.67^{\mathrm{c}}$ & $16.78^{\mathrm{d}}$ \\
$\mathbf{C O N T R O L}$ & $100.00^{\mathrm{a}}$ & $99.67^{\mathrm{d}}$ & $1.01^{\mathrm{d}}$ & $99.35^{\mathrm{a}}$ & $99.33^{\mathrm{a}}$ & $100.00^{\mathrm{a}}$ & $31.17^{\mathrm{abc}}$ \\
ST CHK & $99.33^{\mathrm{a}}$ & $97.83^{\mathrm{d}}$ & $1.03^{\mathrm{d}}$ & $97.12^{\mathrm{ab}}$ & $96.98^{\mathrm{a}}$ & $99.33^{\mathrm{a}}$ & $9.87^{\mathrm{d}}$ \\
$\mathbf{H}$ & $98.00^{\mathrm{a}}$ & $71.39^{\mathrm{d}}$ & $1.70^{\mathrm{a}}$ & $58.97^{\mathrm{e}}$ & $52.72^{\mathrm{c}}$ & $97.83^{\mathrm{a}}$ & $33.94^{\mathrm{ab}}$ \\
$\mathbf{E A}$ & $97.67^{\mathrm{a}}$ & $79.81^{\mathrm{d}}$ & $1.42^{\mathrm{b}}$ & $71.42^{\mathrm{d}}$ & $66.26^{\mathrm{bc}}$ & $97.59^{\mathrm{a}}$ & $42.35^{\mathrm{a}}$ \\
$\mathbf{M}$ & $99.67^{\mathrm{a}}$ & $96.44^{\mathrm{ab}}$ & $1.07^{\mathrm{d}}$ & $93.19^{\mathrm{ab}}$ & $93.98^{\mathrm{a}}$ & $99.63^{\mathrm{a}}$ & $38.06^{\mathrm{a}}$ \\
\hline
\end{tabular}

Data are mean of three replicates; different superscripts in a column indicate significant difference at $P<0.05$.

Table 3. Effect of ethylacetate crude extract dilutions of Parthenium on germination.

\begin{tabular}{|c|c|c|c|c|c|c|c|}
\hline TREATMENTS & GP & GI & MGT & CRG & SE & GE & SVI \\
\hline 10 & $40.67^{b}$ & $26.56^{\mathrm{d}}$ & $1.76^{\mathrm{ab}}$ & $59.07^{b}$ & $39.67^{\text {cde }}$ & $40.67^{b}$ & $1.15^{\mathrm{c}}$ \\
\hline 25 & $30.00^{\mathrm{c}}$ & $19.00^{\mathrm{e}}$ & $1.87^{\mathrm{a}}$ & $54.18^{\mathrm{b}}$ & $35.51^{\text {cde }}$ & $30.00^{c}$ & $0.37^{\mathrm{c}}$ \\
\hline 50 & $14.00^{\mathrm{d}}$ & $9.00^{\mathrm{f}}$ & $2.02^{\mathrm{a}}$ & $50.56^{\mathrm{b}}$ & $27.78^{\mathrm{de}}$ & $14.00^{\mathrm{d}}$ & $0.16^{\mathrm{c}}$ \\
\hline 75 & $2.00^{\mathrm{e}}$ & $1.22^{\mathrm{g}}$ & $0.67^{\text {cd }}$ & $16.67^{\mathrm{c}}$ & $11.11^{\mathrm{ef}}$ & $2.00^{\mathrm{e}}$ & $0.00^{\mathrm{c}}$ \\
\hline 100 & NA & NA & NA & NA & NA & NA & NA \\
\hline CONTROL & $100.00^{\mathrm{a}}$ & $100.00^{\mathrm{a}}$ & $1.00^{\mathrm{bc}}$ & $100.00^{\mathrm{a}}$ & $100.00^{\mathrm{a}}$ & $100.00^{\mathrm{a}}$ & $50.53^{\mathrm{a}}$ \\
\hline ST CHK & $100.00^{\mathrm{a}}$ & $99.00^{\mathrm{a}}$ & $1.02^{\mathrm{bc}}$ & $98.11^{\mathrm{a}}$ & $98.00^{\mathrm{a}}$ & $100.00^{\mathrm{a}}$ & $34.90^{\mathrm{b}}$ \\
\hline H & $98.00^{\mathrm{a}}$ & $71.39^{c}$ & $1.70^{\mathrm{ab}}$ & $58.97^{\mathrm{b}}$ & $52.72^{\mathrm{cd}}$ & $98.00^{\mathrm{a}}$ & $46.17^{\mathrm{ab}}$ \\
\hline EA & $97.67^{\mathrm{a}}$ & $79.81^{b}$ & $1.42^{\mathrm{abc}}$ & $71.42^{b}$ & $66.26^{\mathrm{bc}}$ & $97.67^{\mathrm{a}}$ & $40.24^{\mathrm{ab}}$ \\
\hline M & $99.67^{\mathrm{a}}$ & $96.44^{\mathrm{a}}$ & $1.07^{\mathrm{bc}}$ & $93.19^{\mathrm{a}}$ & $93.98^{\mathrm{ab}}$ & $99.67^{\mathrm{a}}$ & $39.82^{\mathrm{ab}}$ \\
\hline
\end{tabular}

Data are mean of three replicates; different superscripts in a column indicate significant difference at $P<0.05$, NA, not available.

Table 4. Effect of methanol crude extract dilutions of Parthenium on germination.

\begin{tabular}{cccccccc}
\hline TREATMENTS & GP & GI & MGT & CRG & SE & GE & SVI \\
\hline $\mathbf{1 0}$ & $60.00^{\mathrm{b}}$ & $52.11^{\mathrm{d}}$ & $1.29^{\mathrm{abc}}$ & $77.80^{\mathrm{bcd}}$ & $73.43^{\mathrm{ab}}$ & $60.00^{\mathrm{b}}$ & $6.89^{\mathrm{c}}$ \\
$\mathbf{2 5}$ & $52.67^{\mathrm{b}}$ & $44.56^{\mathrm{de}}$ & $1.38^{\mathrm{abc}}$ & $72.83^{\mathrm{cd}}$ & $73.81^{\mathrm{ab}}$ & $52.67^{\mathrm{b}}$ & $3.42^{\mathrm{c}}$ \\
$\mathbf{5 0}$ & $35.33^{\mathrm{c}}$ & $29.33^{\mathrm{ef}}$ & $1.45^{\mathrm{abc}}$ & $71.42^{\mathrm{d}}$ & $67.54^{\mathrm{ab}}$ & $35.33^{\mathrm{c}}$ & $1.76^{\mathrm{c}}$ \\
$\mathbf{7 5}$ & $22.00^{\mathrm{c}}$ & $18.22^{\mathrm{f}}$ & $1.45^{\mathrm{abc}}$ & $69.82^{\mathrm{d}}$ & $67.10^{\mathrm{ab}}$ & $22.00^{\mathrm{c}}$ & $0.35^{\mathrm{c}}$ \\
$\mathbf{1 0 0}$ & $34.67^{\mathrm{c}}$ & $26.86^{\mathrm{ef}}$ & $1.79^{\mathrm{a}}$ & $65.82^{\mathrm{d}}$ & $53.13^{\mathrm{b}}$ & $34.67^{\mathrm{c}}$ & $0.81^{\mathrm{c}}$ \\
CONTROL & $100.00^{\mathrm{a}}$ & $98.61^{\mathrm{a}}$ & $1.04^{\mathrm{bc}}$ & $96.53^{\mathrm{a}}$ & $97.67^{\mathrm{a}}$ & $100.00^{\mathrm{a}}$ & $61.17^{\mathrm{a}}$ \\
ST CHK & $100.00^{\mathrm{a}}$ & $99.50^{\mathrm{a}}$ & $1.01^{\mathrm{c}}$ & $99.03^{\mathrm{ab}}$ & $99.00^{\mathrm{a}}$ & $100.00^{\mathrm{a}}$ & $28.37^{\mathrm{b}}$ \\
$\mathbf{H}$ & $98.00^{\mathrm{a}}$ & $71.39^{\mathrm{c}}$ & $1.70^{\mathrm{ab}}$ & $58.97^{\mathrm{d}}$ & $52.72^{\mathrm{b}}$ & $98.00^{\mathrm{a}}$ & $50.35^{\mathrm{a}}$ \\
EA & $97.67^{\mathrm{a}}$ & $79.81^{\mathrm{bc}}$ & $1.42^{\mathrm{abc}}$ & $71.42^{\mathrm{d}}$ & $66.26^{\mathrm{ab}}$ & $97.67^{\mathrm{a}}$ & $51.27^{\mathrm{a}}$ \\
$\mathbf{M}$ & $99.67^{\mathrm{a}}$ & $96.44^{\mathrm{ab}}$ & $1.07^{\mathrm{bc}}$ & $93.19^{\mathrm{abc}}$ & $93.98^{\mathrm{a}}$ & $99.67^{\mathrm{a}}$ & $56.00^{\mathrm{a}}$ \\
\hline
\end{tabular}

Data are mean of three replicates; different superscripts in a column indicate significant difference at $P<0.05$ 
It has been found that all calculated germination indices except MGT, has significantly changed in hexane extract dilutions (Table-2). Ethyl-Acetate treatments at any dilutions (Table-3) have significant $(\mathrm{P}<0.05)$ effect on all calculated germination indices except MGT. The GP, GI, CRG, SE, GE, SVI showed a reduction trend with increase in concentration. The $100 \%$ ethyl-acetate crude shows least germination followed by $75 \%$ treatment which shows maximum reduction as evident by $\mathrm{GP}(98 \%)$, GI(98.7\%) , $\mathrm{CRG}(83.3 \%)$, $\mathrm{SE}(88.9 \%)$, GE(99.3\%) and SVI(100\%). The lowest concentration $(10 \%)$ of ethyl-acetate crude treatments also show a significant reduction on all germination indices $\operatorname{GP}(59.3 \%)$, GI(73.4\%), CRG(40.93\%), SE(60.33\%), GE(85.33\%) and SVI(97.7\%). Almost similar trend of changes were observed in Methanol treatments. At any dilutions (Table-4) significant $(\mathrm{P}<$ 0.05 ) effect on all calculated germination indices except MGT were observed. The $75 \%$ methanolic treatment shows maximum reduction of germination indices, as evident by $\mathrm{GP}(78 \%), \mathrm{GI}(81.5 \%), \mathrm{CRG}(27.7 \%), \mathrm{SE}(31.3 \%), \mathrm{GE}(84.3 \%)$ and $\mathrm{SVI}(99.4 \%)$ as compared to control. On the contrary there is no significant changes for was noted for the H, EA and M solvents as untreated control. The increasing trend of MGT compared to the decreasing trend of GP, GI, CRG, SE, GE, and SVI indicated a significant inhibition or delay of germination of the test species caused by the Parthenium crude extracts. The overall result show maximum reduction in ethyl-acetate treatments followed by methanol treatments than the hexane treatments.

Parthenium plant extracts have significant effect on seedling growth of $V$. radiata (Fig- 2).
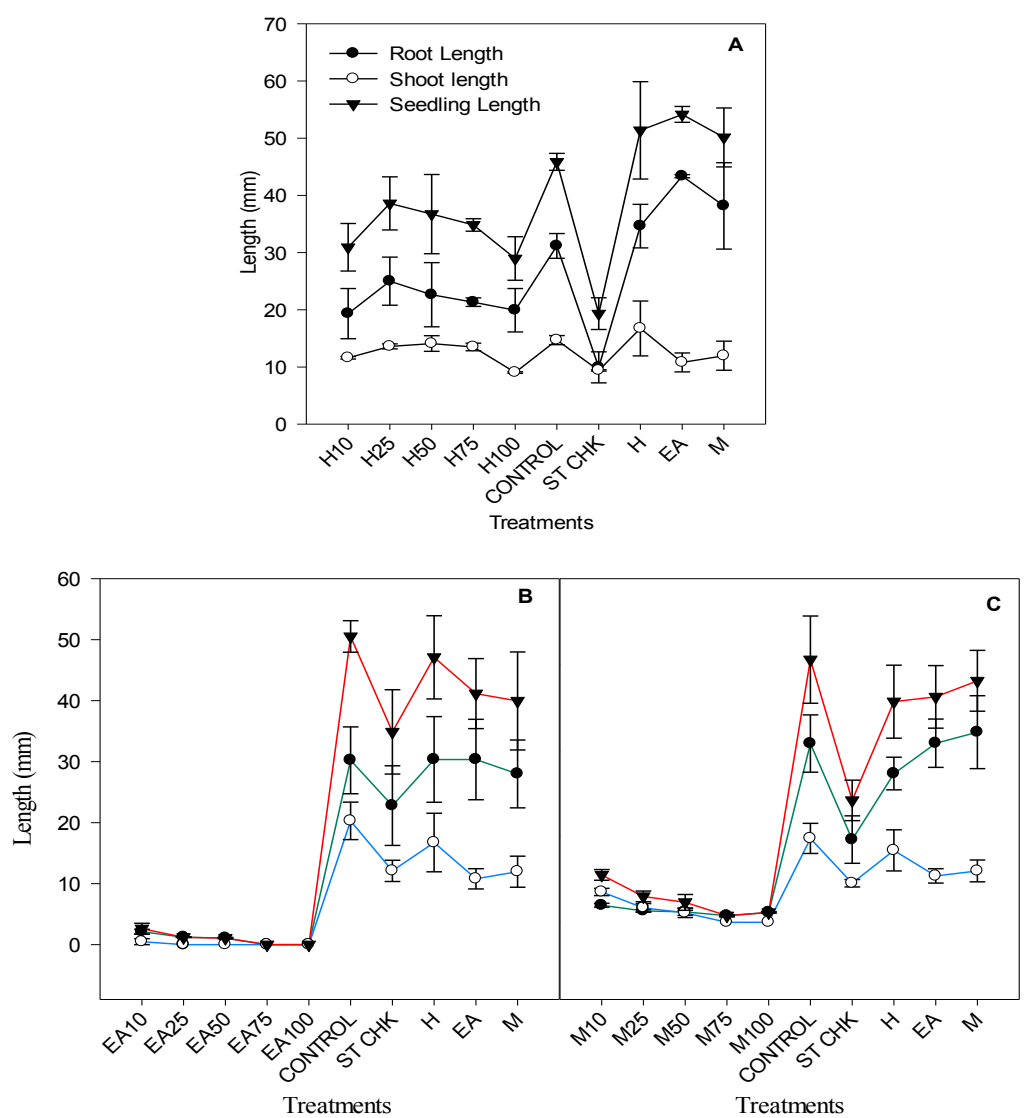

Figure 2. Effect of Parthenium crude extracts on growth (A- hexane; B- ethylacetate; Cmethanol crudes). 
All the ethyl-acetate treatments (Figure-2B) shows inhibitory effect on the root and shoot growth of the test species followed by methanolic treatments (Figure-2C). There is a decreasing trend in root, shoot and seedling growth as the concentration increases except in the hexane treatments (Figure-2A). At $100 \%$ concentration root, shoot and seedling growth was inhibited by 36,39 , and $37 \%$ in respect of control respectively for hexane extract; 100 , 100 and $100 \%$ of control for ethyl-acetate extract; 95,100 and $96 \%$ of control for methanolic extract. The inhibitory effect was greater on the growth of roots than shoot length. The lowest $(10 \%)$ concentration of ethylacetate and methanol crude extracts also shows a similar trend. The gross toxicity potential of Parthenium extracts was corroborated by phytotoxicity and inhibition (Figure-3).
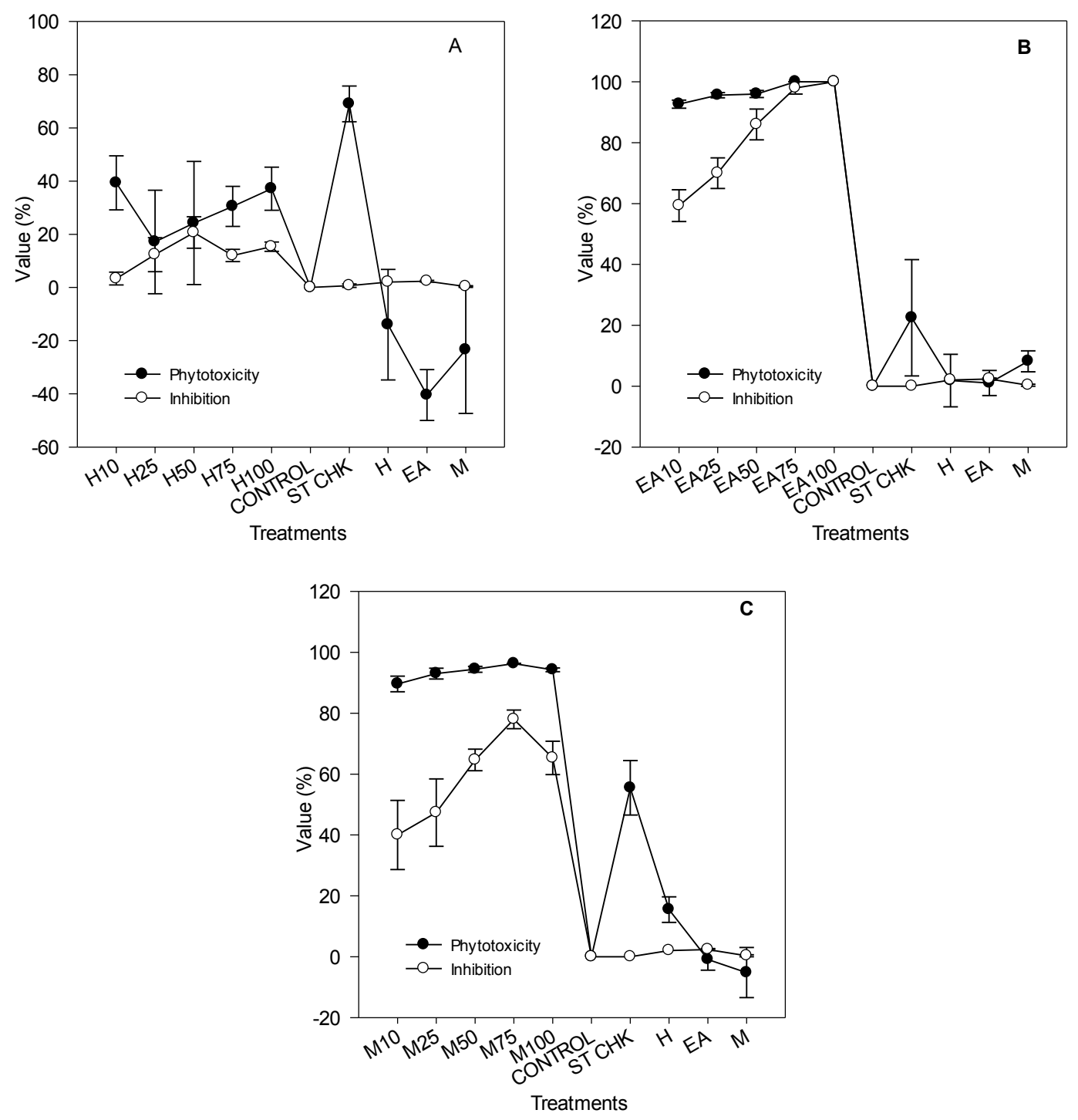

Figure 3. Effect of crude extracts of Parthenium on Phytotoxicity and Inhibition of test species (Ahexane; B- ethylacetate; C- methanol crudes).

At $100 \%$ concentration of hexane extract (Figure-3A) maximum phytotoxicity and inhibition was observed 37 and 15\% respectively. The ethyl-acetate extracts (Figure-3B) and 
methanolic extracts (Figure-3C) of all concentration shows significant $(\mathrm{P}<0.05)$ toxicity on growth of test species. In both the treatments phytotoxicity and inhibition follows a concentration dependent trend as noted earlier for germination studies. At $100 \%$ concentration, phytotoxicity and inhibition was noted by 100 and $100 \%$ respectively for ethylacetate extract; 94 and $65 \%$ for methanolic extract, followed by $75,50,25,10 \%$ concentrations in both treatments.

\section{DISCUSSION}

The allelopathic effect of different concentration of solvent extracts of Parthenium hysterophorus have been found inhibitory to all parameters viz. Seed germination to metabolism of Vigna radiata (mung bean) seeds. Maximum inhibition of germination measured through "germination indices" and growth of Vigna seeds were observed for ethylacetate and methanol crude extracts over hexane extracts. Overall the extract at different concentration reduces germinability and slows down germination kinetics which is considered to be the important visible and reliable indices for the evaluation of Allelopathic Effect. GP index indicated the total germination percent of a seed lot after certain period of time when germination became constant. As it is measured by total germination relative to total number of seeds set for germination, GP cannot explain the delayed germination. In contrast, GI is a measure of both percentage and speed of germination and assigns maximum arithmetic weight to seeds that germinate during first count and less weight to those that germinate later. The higher the GI, GE, SE, SVI, and CRG values compared to control, the lower the inhibition, and vice versa, except for MGT [10]. The delay or inhibition of germination caused by phytotoxic plant extracts or substances was also reported by Anjum [12] and Hussain [13] as also corroborated by Tefera [2], Regina et al, [14].

\section{CONCLUSION}

Therefore in conclusion, ethylacetate and methanolic crudes Parthenium extracts has a strong inhibitory effect on seed germination. However the effect is more prominent in ethylacetate crude extracts over methanol extracts. Hence it could be a potential source of bioherbicide with proper management. Since Parthenium has become a major invasive in different parts of the country. Therefore all efforts should be made to manage its use in bioherbicide formulation which may be beneficial to farmers as well as environment friendly.

\section{References}

[1] J. Picman, and A.K. Picman, Biochemical Systematics and Ecology 12 (1984) 287-297.

[2] T. Tefera, Journal of Agronomy and Crop Science 188 (2002) 306-310.

[3] R. K. Kohli and D. Rani D, Research Bulletin (Science), Punjab University 44 (1984) 105-149.

[4] R.K. Kohli, D. Rani, H.P. Singh, J.K. Pandher, Weed Biology and Management 5 (2005) 105-109.

[5] C.H. Chou, Y.F. Lee, J. Chem. Ecol. 17 (1991) 2267-2281. 
[6] C. Swaminathan, R.R.S. Vinaya, K.K. Sureshi, Int. Tree Crops J. 6 (1990) 143-150.

[7] S.D. Kanchan, Jayachandra, Plant and Soil 55 (1980) 67-75.

[8] D.R. Batish, H.P. Singh, R.K. Kohli, S. Kaur, D.B. Saxena, S. Yadav, Zeitschrift für Naturforschung 62c (2007) 367-372.

[9] International Seed Testing Association, Seed Science Technology 4 (1976) 51-177.

[10] A.K.M.M. Islam, H. Kato-Noguchi, http://dx.doi.org/10.1155/2014/676242.

[11] B.J. Rho, B.S. Kil, J. Nat. Sci. Wankwang Univ 5 (1986) 19-27.

[12] T. Anjum, B. Bajwa, International Journal of Agriculture and Biology 7 (2005) 417419.

[13] M.I. Hussain, L. Gonzalez-Rodriguez, M.J. Reigosa, Allelopathy Journal (22)1 (2008) 101-110.

[14] G.B. Regina, C.F. Reinhardtb, L.C. Foxcroftc, K. Hurlea, Crop Protection, 26 (2007) 237-245. 